\title{
The Effect of Internal and External Conflicts on the Country Trade and Economic Growth: Case from Emerging and Developed Countries
}

\author{
Elham Jafarzadeh ${ }^{1} \&$ He Shuquan ${ }^{2}$ \\ ${ }^{1} \mathrm{Ph} . D$. Student in International Trade, Shanghai University, Shanghai, China \\ ${ }^{2}$ Ph.D. Professor, School of Economics, Shanghai University, Shanghai, China \\ Correspondence: Elham Jafarzadeh, Ph.D. Student in Finance at Shanghai University, Shanghai, China. E-mail: \\ Jafarzadehelham50@gmail.com
}

Received: July 14, 2021

Accepted: August 25, 2021

Online Published: August 28, 2021

doi:10.5539/ijef.v13n9p134

URL: https://doi.org/10.5539/ijef.v13n9p134

\begin{abstract}
The current study investigates the impact of internal conflicts and external conflicts on the overall trade of a country, imports and exports in both developed and emerging markets. The study has used 128 countries for the estimation with data collected from the world bank for the period of 1996 and 2016 using the Hausman test. The results of the random effect showed that internal conflicts and external conflicts have negative impact on the imports and exports of countries in both developing and developed economies.

The findings of the current study have several implications for both academicians and practitioners. The study has provided a deep insight in to the role of internal and external conflicts (a commonly emergent issue) for international trade and economic growth in both developing and developed countries. The current study has broadened the scope of literature on international finance and trade by providing a unique empirical examination on the role of conflicts in international trade and economic growth which is rarely been examined in the literature. Moreover, the study has some practical implications for the policymakers and government to make their international relations as such that to avoid internal and external conflicts if they want to increase international trade and economic growth. More specifically in developing countries there is more prevalence of internal and external conflicts which is the route cause of the lower level of international trade and is one of the important cause of lower level of economic growth.
\end{abstract}

Keywords: internal and external conflicts, imports, exports, economic growth

\section{Introduction}

\subsection{Background}

Trade encourages the reallocation of resources to more efficient activities, and thus opens up opportunities and creates jobs. However, changes in relative prices as a result of trade can also destroy opportunities and jobs in declining sectors, and the people affected by these losses may, under certain conditions, turn to violence as a source of income. Changes in real incomes generated by trade are particularly important in fragile states, where trade flows tend to be larger and more volatile than other external flows, such as aid, remittances and foreign investment.

Intense trading with neighbours reduces the duration as well as the intensity of conflict. This trade reduces the incentives of contiguous countries to fuel civil conflict in their neighbours similarly to the case of inter-state wars. These incentives may be particularly strong in areas, such as much of sub-Saharan Africa, where there are strong ethnic ties across borders. The previous studies have highlighted the inconsistent effect of the internal and external conflicts on bilateral trade that appeal to rational-expectation hypothesis. According to this hypothesis rational traders will forecast the internal conflicts and external conflicts will start reducing their trade with such countries accordingly (Morrow, Siverson, \& Tabares, 1998; Morrow, 1999). Li and Sacko (2002) reported indirect support for the rational expectation hypothesis and found that low level conflicts i.e. external or internal could not affect the bilateral trade till these conflicts reaches to a level of maximum.

However, the rational expectation hypothesis suggests that firm reduces their trade with the anticipation of internal or external conflicts' and these conflicts act as a determinant of cross border trade (Gleditsch, Wallensteen, Eriksson, Sollenberg, \& Strand, 2002). David (2013) concluded that no single theory can explain 
causes of wars and suggested that "if we want to truly understand war, then the first step is to move away from the "magic bullet" theories that purport to fully explain the onset of international war with a single theory". He is of the opinion that various conflicting factors act as a stimulus that make the situation for war.

Extreme conflicts may leads to civil war which can adversely affect the trade volume of the country not only with the trading partners but with also with the other countries due to risk of damages to goods and services or overall business to earn profits. Similarly, different studies have been conducted on the internal and external conflicts and its impact on the risk of lives and damages to business profits by Anderton and Carter (2001); Bayer and Rupert (2004); Gowa (1994); Gowa and Mansfield (1993); Mansfield, Milner, and Rosendorff (2000).

Various studies have been conducted that explain factors that affect the economic growth of country and its heterogeneity in determents among the developed and emerging economies (Blazejowski, Kwiatkowski, \& Gazda, 2019; Ciccone, \& Jarocinski, 2010). In addition to macroeconomic factors, military expenditures are considered as an important detriment of economic growth. For instance, "There is now a large body of empirical literature investigating the economic effects of military spending, with little consensus as to what these effects might be (Dunne, Smith, \& Willenbockel, 2005, p. 449)." Vally (2005) found that war has a negative and significant effect on the on economic growth during the Cold war. However, Organski and Kugler (1977) and Olson (1982) found that internal and external conflicts lead to destruction of resources and rebuilding the same assets with more technological advance techniques leads to which promote higher level economic growth (Schneider, 2014). This study follows the rational expectation and will test the effect of internal and external conflicts on the trade of the country and its economic growth.

\subsection{Research Motivation}

International trade has attracted significant attention of academicians after the current wave of globalization. Various researchers have examined factors affecting international include inflation, interest rate, natural resources trade policy etc. A rich literature is available on the effect of terrorism on the trade (Jackson, Dixon, \& Greenfield, 2007), whereas, other specific sectors studies showed adverse effect of terrorism on growth of countries (Drakos \& Kutan, 2003). Another stream of studies found adverse effects of terrorism and conflicts on the foreign direct investments (Abadie \& Gardeazabal, 2008; Bandyopadhyay, Sandler, \& Younas, 2014), the significant negative effect of conclicts have been examined in case of bilateral trade by Blomberg and Hess (2006) and Magee and Massoud (2011). However, the role of internal and external conflicts has not been examined extensively in literature. The current study main motivation is due to the prevalence of internal and external conflicts in countries and mostly such countries are lag behind in the international trade as well as their economic growth is constrained relative to the other countries of their neighbourhoods with the same resources. So, this research study intends to investigate that is there any relationship of the internal and external conflicts with international trade while controlling for the macroeconomic variations. Further, the study also examined that the effect of the conflicts on the overall country economic growth.

\subsection{Research Questions}

This work examines aims to study the effect that internal and external conflicts have on the economic growth of developed and emerging countries and revolves around the following question: What is the effect of internal and external conflicts on the economic growth in developed and emerging countries? And also, to test that how country risk affects the economic growth of developed and emerging countries?

\subsection{Research Objectives}

The current research study has the following objectives;

- To investigate the effect of internal conflicts on the country trade in developed and emerging countries;

- To investigate the effect of external conflicts on the country trade in developed and emerging countries;

- To examines the effect of internal conflicts on the country economic growth in developed and emerging countries;

- To investigate the effect of country risk on the country trade in developed and emerging countries;

- To examine the effect of external conflicts on the country economic growth in developed and emerging countries;

- To examine the effect of economic growth in developed and emerging countries.

\subsection{Research Significance}

This research study has several importance for various stakeholders, for instance this study has significance for 
the corporate sectors or business sectors, importers and exporters as the findings of the study will address them regarding the influence of the internal as well as external conflicts on trade. Further, it also elaborates the investors that how these conflicts affect the economic growth of the companies.

The findings of the study also be helpful for the country political leadership and administration as it explains them that how the internal and external conflicts can affect the trade of a country and in turn how it affects the economic growth and well-being of the people. It also helps the policymakers also to consider the internal and external conflicts while making any trade policy and may take significant steps in reducing the conflicts.

\subsection{Research Contributions}

The effect of internal and external conflicts on trade is an interesting and debatable issue which got considerable attention of the researchers, policymakers, country administration and business community. Most of the studies considered the effect of terrorism on the trade and economic growth patterns of the host countries (Jackson, Dixon, \& Greenfield, 2007; Blomberg, Hess, \& Orphanides, 2004; Gaibulloev \& Sandler, 2008, 2011), another stream of studies examined sector specific effect of the terrorism on the economic growth (Drakos \& Kutan, 2003; Enders, Sandler, \& Parise, 1992) and negative effect of the terrorism and conflicts on the foreign direct investments (Abadie \& Gardeazabal, 2008; Bandyopadhyay, Sandler, \& Younas, 2014; Enders \& Sandler, 1996), whereas there is a negative effect of the conflicts on bilateral trade is examined by Blomberg and Hess (2006); Mirza and Verdier (2014); Nitsch and Schumacher (2004), Magee and Massoud (2011) shows that how trade affect the stability of a country, whereas, Bussman and Schneider (2007); D'Souza (2013) examined the effect of conflicts on trade and find significant and negative effect on the trade.

The current study is different from the prior studies on the following grounds;

- Firstly, this is the first study that investigate the effect of the internal conflicts and external conflicts on the imports, exports and total trade of countries in both emerging and developed countries.

- Secondly, this study also considers country risk as an important concept and will test its effect on the imports, exports and total trade in both the emerging and developed economies which is not studied till date.

- Thirdly, economic growth is an important factor that may be affected by the conflicts between different countries therefore; this study will also investigate that how the internal and external conflicts affect the economic growth of countries belonging to emerging and developed economies which is also not considered by any researcher.

- Fourthly, the study also examines that how the overall country risk is associated with the country economic growth and will also test that is there any difference in the association of country risk and economic growth in case of emerging and developed countries.

- Lastly, this study also considers other important variables such as country governance and economic and monetary freedom and its effect on the trade and economic growth. Furthermore, this study will also consider macroeconomic factors that may affect the trade and economic growth.

\subsection{Research Methodology}

The current study is applied in nature which will take in to account the rational expectation hypothesis which states that internal and external conflicts negatively related with trade. The study followed explanatory research design to test the hypothesis that internal and external conflicts have significant and adverse effect on the internal trade.

The study will also test the effect of internal and external conflicts on economic growth by controlling for the negative effects of the international trade due to such conflicts. As this is applied research the study collected data from the World Bank Development with a total of 128 countries from 1996 to 2016. The study has followed panel data estimation techniques for the purpose of analysis and estimations of results.

Various research models were specified for the estimation purpose in order to test the relationship of internal and external conflicts with international trade used by Aker (2008) for imports with inclusion of internal and external conflicts and economic freedom used by Singhania and Saini (2017), Afaq and Khan (2016) and Byrne and Fiess (2015). The exports models were adopted from the study of Majeed and Ahmad (2006) and Zada, Muhammad and Bahadar (2011).

\section{Literature Review}

A considerable attention has been given to the rational-expectation hypothesis, consequences of internal and external conflicts, internal and external conflicts and foreign capital inflows, and the economic Growth. 


\subsection{Rational-Expectation Hypothesis}

The previous studies have highlighted the inconsistent effect of the internal and external conflicts on bilateral trade appeal to rational-expectation hypothesis. According to this hypothesis rational traders will forecast the internal conflicts and external conflicts will starting reduce their trade with such countries accordingly (Morrow, Siverson, \& Tabares 1998; Morrow, 1999). However, the rational expectation hypothesis suggests that firm reduces their trade with the anticipation of internal or external conflicts' and these conflicts act as a determinant of cross border trade (Gleditsch, Wallensteen, Eriksson, Sollenberg, \& Strand, 2002). This study will follow the rational expectation hypothesis and will test the effect of internal and external conflicts on trade of the country and its economic growth.

$\mathrm{Li}$ and Sacko (2002) reported indirect support for the rational expectation hypothesis and found that low level conflicts i.e. external or internal could not affect the bilateral trade till these conflicts reaches to a maximum level. Extreme conflicts may lead to civil war which can adversely affect the trade volume of the country not only with the trading partners but with also other countries due to risk of damages to goods and services or overall business to earn profits. Similarly, different studies have been conducted on the internal and external conflicts and its impact on the risk of lives and damages to business profits by Anderton and Carter (2001); Bayer and Rupert (2004); Gowa (1994); Gowa and Mansfield (1993); Mansfield, Milner, and Rosendorff (2000). Moreover, we can anticipate that low level conflict either internal or external will also adversely affect the trade; however, different studies reported inconsistent results on the relationship of militarized disputes and trade (Bliss \& Russett, 1998; Kim, 1998; Morrow, Siverson, \& Tabares, 1999; Keshk, Pollins, \& Reuveny, 2004).

\subsection{Consequences of Internal and External Conflicts}

The literature highlighted various reasons that internal and external conflicts discourage the trade and negatively affect the firm profits. Trade encompasses "those transactions that involve a physical movement of goods or a tangible commitment of economic resources" (Krugman \& Obstfeld, 1994). The conflicts create a probability to damage property which directly affect the cost of transportations. For instance, the exports of goods or services involved various resources such as employees and freight charges and vehicles such as ship or truck etc, conflicts in a country threaten these resources which leads to increase in costs. In order to reduce these losses firms may enter in to insurance contracts which in turns increase the cost of doing business (Berman, 2000; Howell, 1998; Wagner, 1999) and the exporters are changed for this insurance.

These greater transactions cost would leads to increase in the exporting goods or services prices in market and it varies directly with the level of conflicts in a country. To put it in a simple words' transaction costs is "the costs of arranging a contract ex ante and monitoring and enforcing it ex post, as opposed to production costs, which are the costs of executing the contract" (Matthews, 1986, p. 906). Thus, the higher is the conflicts in a country the higher would be the transaction cost the lower would be the profits margin of for the company (Anderson \& Marcouiller, 2002).

Drakos and Kutan (2003) consider tourism industry and examined that how terrorist activities could directly and indirectly influence the foreign direct investments. By direct they mean that these terrorists activities causing damages to assets and human capital of investors whereas the indirect affect showed that terrorists activities has increased the cost of advertisement to be done to attract the tourists and costs of construction of the tourists spots damaged and thus negatively influence the foreign direct investments.

The literature shows that conflicts affect the firm profits in two ways; the direct effect due to damage in property, infrastructure goods and services and loss to human resources, while the indirect effect is due to the cost of transactions which adversely affect the industry prevailing in a country and creates hindrance in the economic growth of a country. Another stream of studies reported that high level of conflicts damages the private and social capital and shifts it to the unproductive sectors such as purchase of weapons and recruitment of more solders (Murdoch \& Sandler, 2002). Moreover, Barro (1991); Imai and Weinstein (2000) suggested that civil conflicts in country adversely affected the economic growth due to less domestic and foreign capital inflows to the country. Hansen (1990) suggested that conflicts between countries lead to change in the economic and political policy towards foreign business or cross border trade. This change in hostile polices may lead to expropriation of assets and profits and confiscation of property or assets of firms operating in the enemy countries which discourage the foreign direct investments and adversely affect the economic growth.

Leblang and Satyanath (2006) highlighted that conflicts between countries discourage the investors to invest in such countries which directly affect the foreign currency reserve used for the foreign trade purpose. Therefore, decrease in the foreign currency reserves and would constraint the foreign trade due to non-availability of foreign currency (Sobek, 2013). The internal or external conflicts effect the political institutions that regulate 
industry and enforce contracts. In times of conflicts these institutions failed to compensate firms in case of any discrepancy in contract (Sobek, 2013).

David (2013) concluded that no single theory can explain causes of wars and suggested that "if we want to truly understand war, then the first step is to move away from the "magic bullet" theories that purport to fully explain the onset of international war with a single theory". He is of the opinion that various conflicting factors act as a stimulus that make the situation for war.

Ali, Fiess, and MacDonald (2010) suggested that property rights security and institutions have negative effect on the foreign direct investments. Hayakawa, Kimura, and Lee (2013) also examined the relationship between the country risk and foreign direct investments inflows. They considered the whole composite index of country risk as well as its components i.e. political risk and financial risk. Their results show that country risk has significant and negative effect on the foreign direct investment inflows and also found that both the political and financial risk adversely affected the foreign capital inflows.

Another stream of studies found that internal conflicts as well as external conflicts and country risk have insignificant effect on the foreign direct investments. For instance, the study conducted by the Wheeler and Mody (1992) while using firms' level data of US found insignificant relationship of the country risk and corruption. Noorbakhsh, Paloni, and Youssef (2001) and Asiedu (2002) also reported no significant effect of the political risk on the foreign direct investments' inflows.

\subsection{Internal and External Conflicts and Foreign Capital Inflows}

A good number of studies examine the effects of internal and external conflicts and its effect on the foreign capital inflows. Specifically, Drakos and Kutan (2003) found a negative effect of the terrorist attacks on the foreign direct investment inflows in to the country. Nitsch and Schumacher (2004) examined the relationship between terrorism and international trade. They used bilateral trade data from 1960 to 1993 for 200 countries and found that terrorist activities negatively affect the trade volume. Daniele and Marani (2010), found that in the presences of trade incentive, crime performed by the mafia negatively and significantly associated with the foreign direct investments' inflows. They also concluded that more crimes execution negatively affects the institutional environment which in turns adversely affect the attraction for the foreign direct investments' inflow.

In similar manner, Ashby and Ramos (2013) conducted study in Mexico and found that organized crime is found to have a negative and significant effect on the attraction for business activities and investments. They also examine the effect of crime on foreign direct investments inflows to various industries and found negative effect of on the commerce, agriculture and financial services and oil and mining industry. Bandyopadhyay et al. (2013) conducted study by using data of 78 developing countries from 1984-2008 and found negative effect of the terrorism on foreign direct investments.

The existing literature showed that increased armed conflicts is negatively associated with the investments and also negatively affect the infrastructure and regulatory institutions. Ezeoha and Cattaneo (2013), Calderon and Serven (2010); Herger et al. (2008) reported that good governance and quality of institutions of host country positively affected the foreign direct investments. However, organized crimes and armed conflicts adversely affect these institutions and quality of good governance which leads to further increase in costs and decrease in the foreign direct investments (Benassy-Quere et al., 2007; Drakos \& Kutan, 2003).

Another stream of studies has examined the influence of the foreign direct investments stock provide an incentive to increased country security. Oetzel et al. (2007) and Nitsch and Schumacher (2004) are of the opinion that flow of funds between the countries in terms of bilateral trade help the partnering countries to improve their respective countries security and networking in the region. Therefore, it is followed from the results that agreement between the host and home country of foreign direct investments has negative effect of the conflicts. The reason of this negative effect can be due to the fact that bilateral agreements make the country to improve their security up to the level that they could easily managed the insurgencies due to global competition for international resources. For instance, in the case of Ivory Coast, substantial "foreign military presence may increase the likelihood that foreign investors will retain confidence to continue investing" (Think Africa Security, 2010).

$\mathrm{Li}$ and Vashchilko (2010) also suggested that even in the presence of conflicts and insurgencies the flow of the foreign direct investments will increase provided that the investing and recipient countries could have improved their security alliances. Various studies have reported that country with lower level of risk would attract more foreign direct investments inflows (Helpman, Melitz, \& Yeaple, 2004). Furthermore, country risk is also a combination of political risk which is due to institutional quality and negatively affects the returns on 
investments and financial risk which create a sunk cost for acquiring the multinational companies (Helpman, Melitz, \& Yeaple, 2004).

In similar manner, Gastanaga, Nugent, and Pashamova (1998) considered a sample of 22 developing countries and found that lower probability of nationalization of multinational corporations and corruption is positively associated with the foreign direct investments. Wei (2000) also reported that the level of corruption is negatively associated with the foreign capital inflows. Kolstad and Tøndel (2002) reported that foreign direct investment is negatively affected by the internal tensions, democracy, bureaucracy and law and order situation. Busse and Hefeker (2007) also concluded that internal as well as external conflicts, law and order and low level of accountability has negatively affected the foreign direct investments.

\subsection{Economic Growth}

Economic growth has been considered as an important topic to academia, researchers, policymakers and regulatory bodies. Various studies have been conducted that explain factors that affect the economic growth of country and its heterogeneity in determents among the developed and emerging economies (Blazejowski, Kwiatkowski \& Gazda, 2019; Ciccone, \& Jarocinski, 2010). In addition to macroeconomic factors, military expenditures are considered as an important detriment of economic growth. For instance, "There is now a large body of empirical literature investigating the economic effects of military spending, with little consensus as to what these effects might be (Dunne, Smith, \& Willenbockel, 2005, p. 449)."

The literature shows that the cost of war is damaging the host country even if it is very small. Vally Koubi (2005) found that war has a negative and significant effect on the on economic growth during the Cold war. However, Organski and Kugler (1977) and Olson (1982) found that internal and external conflicts lead to destruction of resources and rebuilding the same assets with more technological advance techniques leads to which promote higher level economic growth (Schneider, 2014). As argued by Sandler (2011) reported that countries show their concern over the internal and external conflicts which affect the business and their functions and negatively affect the capital inflows to the country (De Groot, 2010). Murdoch and Sandler (2002a) investigated the spill over effect of the war on the country's economic growth and found that wars negatively affect the economic growth of the country and also the economic growth of the intensive trading partners (Dunne \& Tian, 2013). "All wars are fought for money" is the anti-war slogan attributed to Socrates, and George Orwell wrote in a book review that War against a foreign country only happens when the moneyed classes think they are going to profit from it" (Orwell, 1937/1998, p. 75).

\section{Methodology}

This research study intends to investigate that is there any relationship of the internal and external conflicts with international trade while controlling for the macroeconomic variations. Further, the study also examined that the effect of the conflicts on the overall country economic growth.

\subsection{Data and Source}

The database used for the estimation of this study was collected from the World Bank database. This study has used a total of 128 countries for the estimation. The time period of the data start from 1996 to 2016 and will be processed using STATA software.

\subsection{Research Model}

The study followed the baseline model of Aker (2008) for imports with inclusion of internal and external conflicts and economic freedom used by Singhania and Saini (2017), Afaq and Khan (2016) and Byrne and Fiess (2015). Furthermore, for the exports the model of Majeed and Ahmad (2006) and Zada, Muhammad and Bahadar (2011). The study has followed panel data analysis for the estimation of regression models. This study estimated random and fixed effect models and then used Hausman test to decide which model fit the best our data.

Following the objective of the study as mention in the introduction, the model is econometrically estimated as follow:

Model 1:

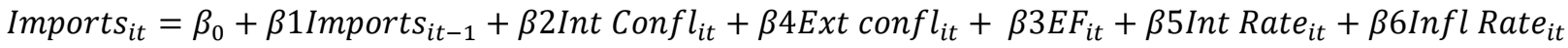
$+\beta 7 B F_{i t}+\beta 8 T F_{i t}+\beta 9$ Employment $_{i t}+\beta 10 G C F_{i t}+\beta 11$ Tax $_{i t}+\beta 12 E F I_{i t}+\beta 13 F R_{i t}+\varepsilon_{i t}$

Model 2:

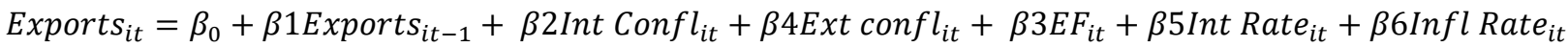
$+\beta 7 B F_{i t}+\beta 8 T F_{i t}+\beta 9$ Employment $_{i t}+\beta 10 G C F_{i t}+\beta 11 T a x_{i t}+\beta 12 E F I_{i t}+\beta 13 F R_{i t}+\varepsilon_{i t}$ 
Model 3:

$$
\begin{gathered}
\text { Total Trade }_{i t}=\beta_{0}+\beta 1 \text { Total Trade }_{i t-1}+\beta 2 \text { Int Confl } \\
\text { T6Infl }
\end{gathered}
$$

Model 4:

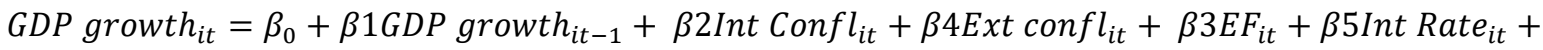

$$
\begin{aligned}
& \beta 6 \text { Infl Rate } i t+\beta 7 B F_{i t}+\beta 8 T F_{i t}+\beta 9 \text { Employment }_{i t}+\beta 10 G C F_{i t}+\beta 11 \text { Tax }_{i t}+\beta 12 E F I_{i t}+ \\
& \beta 13 F R_{i t}+\varepsilon_{i t}
\end{aligned}
$$

With $\beta 0$ the constant and $\varepsilon_{i t}$ : the error term, $\beta_{1}=\beta_{13}$ Coefficient of independent variables.

$\mathrm{BF}=$ Business freedom; $\mathrm{TF}=$ Trade freedom; $\mathrm{E}=$ Employment $; \mathrm{CGF}=$ Gross capital formation; $\mathrm{Ext}$ Conft $=$ External conflicts; EFI = Economic freedom index; Infl R = Inflation rate; Int R = Interest rate; FR = Foreign reserve

\subsection{Definition of the Variables}

\subsubsection{External Conflicts}

The current study has measured external conflicts as ratings assigned to each country for the sample period of the International country risk guide. Further the same was converted in to percentage change as to avoid scaling problem as most of the variables used in the study are in percentage form.

\subsubsection{Economic Growth}

Economic growth is measured through the gross domestic product. The study has used growth in the gross domestic product as a proxy for the economic growth. The growth has been computed from changes in gross domestic product from current year minus previous year scaled by previous year (Buhaug \& Rød, 2006; and Dunne \& Tian, 2013).

\subsubsection{Imports and Exports}

Imports and exports are used as proxy for international trade. The study has taken imports and exports in dollars and the same is divided by the gross domestic products in order to have the value in terms of ratios of both import to gross domestic products and exports to gross domestic products (Aker, 2008). Furthermore, the study has also used total trade done in a country and the same is divided by gross domestic products used as a robust measure for the imports and exports (Zada, Muhammad, \& Bahadar, 2011).

\subsubsection{Economic Freedom}

In order to control of the business environmental factors, the study has used an economic freedom composite index as computed by Heritage foundation that has been proved to be an important factor that can affect the country business and trade. This study also considered economic freedom and also its sub components that are more related to business such as trade freedom and business freedom as a proxy for the overall business conducive environment that could affect imports, exports and overall trade of a country (Singhania \& Saini 2017; Afaq \& Khan, 2016).

\subsubsection{Control Variables}

The study also considered various macroeconomic variables to control for their effect on the main variables of interest i.e. imports, exports and total trade. The control variables include inflation rate, employment rate of a country, gross capital formation to gross domestic products, foreign reserves to gross domestic products, tax on trade and custom duties are taken as macroeconomic variables used in the study to account for the country specific variables.

\section{Empirical Result Analysis}

This section will present the empirical results obtained during the regression of our data on the STATA software from 1996 to 2016 which the general purpose to see if the external conflicts has an effect on the economic growth of the country. The section includes various types of statistical tests results such as descriptive statistics, Pearson correlation, pool regression, random effect and fixed effect regression models.

\subsection{Descriptive Statistic}

Table 1 of the research analysis represents the descriptive statistics of the variables used in the study. The average value of import to gdp is 0.479 , export to gdp is 0.432 and total trade to gdp is 0.886 percent. Moreover, the average value of the internal conflicts rating is 0.856 , whereas, external conflicts 0.992 it shows that the 
sample countries are having more external conflicts as compared to internal conflicts. Furthermore, the study used control variables such as GDP growth which has an average value of 0.038 , inflation rate is 0.057 , foreign reserve for trade 0.048 , gross capital formation to total gdp is 0.234 , average interest rate is 0.038 , average employment rate is 8.8 percent, economic freedom has an average value of 1.78 , whereas, on average tax rate is $1.87 \%$, trade freedom has an average value of 1.87 and business freedom has an average value of 1.808 . The descriptive statistics showed that the data is normal and there is no significant higher deviations or outliers in the data.

Table 1. Descriptive statistics

\begin{tabular}{|c|c|c|c|c|c|}
\hline Variable & Obs & Mean & Std. Dev. & Min & Max \\
\hline imp_gdp & 1485 & .479 & .381 & 0 & 4.276 \\
\hline exp_gdp & 1485 & .432 & .334 & 0 & 2.29 \\
\hline tt_gdp & 1485 & .886 & .62 & 0 & 4.426 \\
\hline Iconft & 1485 & .856 & .083 & .602 & 1.061 \\
\hline Econft & 1485 & .992 & .057 & .73 & 1.079 \\
\hline Gdpg & 1485 & .038 & .055 & -.621 & 1.231 \\
\hline Inf & 1485 & .057 & .078 & -.276 & .753 \\
\hline FResv & 1485 & .048 & .059 & 0 & .792 \\
\hline gcf_gdp & 1485 & .234 & .089 & 0 & .582 \\
\hline Intr & 1485 & .038 & .061 & -.132 & .49 \\
\hline Emp & 1485 & 8.813 & 2.844 & 0 & 13.524 \\
\hline Efi & 1485 & 1.785 & .08 & 1.33 & 1.955 \\
\hline Tax & 1485 & 1.87 & .082 & 1.515 & 2 \\
\hline Tfreedom & 1485 & 1.876 & .071 & 1.176 & 1.978 \\
\hline Bfreedom & 1485 & 1.808 & .129 & 1 & 2 \\
\hline
\end{tabular}

Source author: STATA.

\subsection{Pearson Correlation}

Table 2 represents the results of the Pearson correlation between the variables used in the study. The correlation is used to find-out that how each variable is connected with the other variables and to find-out the direction and strength of the connection among different variables. The results reported in the table 2 showed that import to gdp, exports to gdp and total trade to gdp have negative association with the internal and external conflicts faced by a country. Thus, these negative linkages showed that internal and external conflicts have adverse effect on the imports, exports and total trade of a country. Moreover, in case of control variables taxes and duties on trade and inflation rates are found negative in effect on the import, export and total trade of a country. Whereas, the results also portray that there is a positive association of gdp growth, inflation, foreign reserves for trade, capital formation, employment rate, economic freedom, trade freedom and business freedom. Thus, increase in the gdp growth of a country and more foreign reserves, more employment in a country and high capital formation would significantly improve the imports, exports and overall trade in a country. Moreover, the relatively higher level of economic freedom of a country with trade freedom and business freedom would have higher level of imports, exports and total trade.

Table 2. Matrix of correlations

\begin{tabular}{|c|c|c|c|c|c|c|c|c|c|c|c|c|c|c|c|}
\hline Variables & (1) & (2) & (3) & (4) & (5) & (6) & (7) & (8) & (9) & (10) & (11) & (12) & (13) & (14) & $\overline{(15)}$ \\
\hline (1) Imp_gdp & 1.000 & & & & & & & & & & & & & & \\
\hline (2) Exp_gdp & 0.067 & 1.000 & & & & & & & & & & & & & \\
\hline (3) $\mathrm{tt}$ gdp & 0.100 & 0.973 & 1.000 & & & & & & & & & & & & \\
\hline (4) Iconft & -0.089 & -0.137 & -0.112 & 1.000 & & & & & & & & & & & \\
\hline (5) Econft & -0.025 & -0.303 & -0.295 & 0.096 & 1.000 & & & & & & & & & & \\
\hline (6) gdpg & 0.013 & 0.036 & 0.032 & 0.165 & -0.040 & 1.000 & & & & & & & & & \\
\hline (7) $\mathrm{Inf}$ & 0.077 & -0.125 & -0.126 & 0.035 & -0.140 & 0.148 & 1.000 & & & & & & & & \\
\hline (8) Fresv & 0.039 & 0.064 & 0.116 & 0.110 & -0.097 & 0.002 & 0.018 & 1.000 & & & & & & & \\
\hline (9) gcf_gdp & 0.014 & 0.137 & 0.174 & 0.129 & 0.027 & 0.184 & 0.059 & 0.067 & 1.000 & & & & & & \\
\hline (10) Intr & -0.027 & -0.120 & -0.096 & -0.023 & 0.031 & 0.053 & 0.123 & 0.166 & -0.025 & 1.000 & & & & & \\
\hline (11) Emp & 0.062 & 0.116 & 0.110 & -0.046 & 0.014 & 0.004 & -0.041 & -0.025 & 0.285 & -0.076 & 1.000 & & & & \\
\hline (12) Efi & 0.159 & 0.383 & 0.359 & 0.043 & 0.286 & -0.123 & -0.279 & -0.126 & 0.109 & -0.046 & 0.144 & 1.000 & & & \\
\hline (13) Tax & -0.103 & -0.076 & -0.083 & 0.153 & -0.116 & 0.126 & 0.182 & 0.196 & 0.137 & 0.256 & -0.024 & -0.010 & 1.000 & & \\
\hline (14) Tfreedom & 0.052 & 0.310 & 0.293 & 0.056 & 0.314 & -0.062 & -0.170 & -0.104 & 0.052 & 0.016 & 0.091 & 0.672 & -0.065 & 1.000 & \\
\hline (15) Bfreedom & 0.103 & 0.283 & 0.265 & 0.032 & 0.188 & -0.101 & -0.135 & -0.121 & 0.133 & -0.055 & 0.113 & 0.793 & -0.095 & 0.518 & 1.000 \\
\hline
\end{tabular}

Souce author: STATA. 


\subsection{Regression Results of Imports}

Table 3. Regression results of imports

\begin{tabular}{|c|c|c|c|}
\hline IMP_GDP & $\begin{array}{r}\text { (Model-1) } \\
\text { Pool Effect } \\
\end{array}$ & $\begin{array}{c}\text { (Model-2) } \\
\text { Random Effect }\end{array}$ & $\begin{array}{r}\text { (Model-3) } \\
\text { Fixed Effect }\end{array}$ \\
\hline Internal conflicts & $\begin{array}{c}-0.561 * * * \\
(0.001)\end{array}$ & $\begin{array}{c}-0.732 * * * \\
(0.006)\end{array}$ & $\begin{array}{c}-0.714 * * * \\
(0.009)\end{array}$ \\
\hline External conflicts & $\begin{array}{c}-0.230 * * * \\
(0.018)\end{array}$ & $\begin{array}{c}-0.258 * * * \\
(0.019)\end{array}$ & $\begin{array}{c}-0.256^{* * * *} \\
(0.020)\end{array}$ \\
\hline Gdp growth & $\begin{array}{c}0.142 * * \\
(0.068)\end{array}$ & $\begin{array}{c}0.094 * * \\
(0.040)\end{array}$ & $\begin{array}{c}0.091 * * * \\
(0.032)\end{array}$ \\
\hline Inflation & $\begin{array}{c}0.341^{* *} \\
(0.155)\end{array}$ & $\begin{array}{l}0.145^{* *} \\
(0.070)\end{array}$ & $\begin{array}{l}0.151^{* *} \\
(0.070)\end{array}$ \\
\hline Reserve & $\begin{array}{l}0.452 * * \\
(0.183)\end{array}$ & $\begin{array}{l}0.246^{* *} \\
(0.105)\end{array}$ & $\begin{array}{l}0.482 * * \\
(0.222)\end{array}$ \\
\hline gcf_gdp & $\begin{array}{r}0.268^{* *} \\
(0.108)\end{array}$ & $\begin{array}{r}0.189^{* *} \\
(0.082)\end{array}$ & $\begin{array}{l}0.178^{* *} \\
(0.084)\end{array}$ \\
\hline Interest rate & $\begin{array}{c}-0.402 * * * \\
(0.150)\end{array}$ & $\begin{array}{c}-0.210 * * \\
(0.105)\end{array}$ & $\begin{array}{c}-0.451 * * \\
(0.221)\end{array}$ \\
\hline Employment rate & $\begin{array}{l}0.013^{* * * *} \\
(0.003)\end{array}$ & $\begin{array}{l}0.006^{* *} \\
(0.003)\end{array}$ & $\begin{array}{c}0.003 * * * \\
(0.001)\end{array}$ \\
\hline Economic freedom index & $\begin{array}{l}1.661 * * * \\
(0.289)\end{array}$ & $\begin{array}{l}0.581 * * \\
(0.258)\end{array}$ & $\begin{array}{l}0.392 * * \\
(0.192)\end{array}$ \\
\hline Tax & $\begin{array}{c}-0.755^{* * * *} \\
(0.114)\end{array}$ & $\begin{array}{c}-0.247 * * \\
(0.119)\end{array}$ & $\begin{array}{c}-0.401 * * \\
(0.203)\end{array}$ \\
\hline Trade freedom & $\begin{array}{c}0.623 * * * \\
(0.172)\end{array}$ & $\begin{array}{c}0.468 * * * \\
(0.123)\end{array}$ & $\begin{array}{c}0.463 * * * \\
(0.126)\end{array}$ \\
\hline Business freedom & $\begin{array}{l}0.310^{* *} \\
(0.125)\end{array}$ & $\begin{array}{c}0.361 * * * \\
(0.103)\end{array}$ & $\begin{array}{c}0.611 * * * \\
(0.106)\end{array}$ \\
\hline Imports(t-1) & $\begin{array}{l}0.023 * * * \\
(0.003)\end{array}$ & $\begin{array}{l}0.032 * * \\
(0.003)\end{array}$ & $\begin{array}{c}0.033 * * * \\
(0.001)\end{array}$ \\
\hline _cons & $\begin{array}{c}0.089 \\
(0.359)\end{array}$ & $\begin{array}{l}0.780^{*} \\
(0.461)\end{array}$ & $\begin{array}{c}0.714 \\
(0.512)\end{array}$ \\
\hline Obs. & 1485 & 1485 & 1485 \\
\hline $\begin{array}{l}\text { R-squared } \\
\text { Hausman Statistics }\end{array}$ & 0.361 & 0.233 & $\begin{array}{c}0.223 \\
11.56(0.000)\end{array}$ \\
\hline
\end{tabular}

Standard errors are in parenthesis $* * * \mathrm{p}<0.01, * * \mathrm{p}<0.05, * \mathrm{p}<0.1$

Souce author: STATA.

Table 3 represents the results for the imports to GDP as a dependent variable. The explanatory variables include internal conflicts and external conflicts as main variables of interest. Whereas, other explanatory variables include GDP growth, inflation rate, gross capital formation to GDP, interest rate, employment rate as country specific factors. Moreover, business environment related factors include foreign reserves, economic freedom index, tax duties on trade, trade freedom and business freedom. The Table 3 showed results of three models where Model 1 represents results of pool effect, Model-2 represents results of random effects and model-3 represent results of fixed effect model. For the selection of best model that fit the data well is decided on the basis of Hausman test which showed that its calculated value is 11.56 with p-value of 0.000 which is less than the critical value at $5 \%$ level of significance. Therefore, random effect model is preferred over the fixed effect model. Therefore, we will interpret our results based on the random effect modelling.

The results of the random effect model showed that internal and external conflicts have a negative as well as significant effect on the imports to GDP. Thus, countries with higher rate of internal conflicts and external conflicts will have negative influence on the imports of a country. It is mainly due to the fact that internal conflicts reduce the purchasing power of the people up to the extent that they could reduce their spending on imported goods. Whereas, the external conflicts adversely affect the relationship between the countries that leads to create trade barriers in the form of taxes and high duties on imports of goods of the rivalry countries. 
Therefore, both internal conflicts' as well as external conflicts' can negatively affect the imports of goods. These results are in line with the results of the Martin et al. (2008) Glick and Taylor (2005) and Lamotte (2012) also found significant negative effect of war and conflicts on the trade.

The results of the other variables such as GDP growth, inflation, gross capita formation, employment rate is found to have a positive and significant influence on the imports of goods and services. Thus, countries with positive GDP growth, high inflation rate, more gross capital formation and higher employment rate could positively affect imports of goods and services. However, interest rate and taxes or duties on trade has negative influence on the import of goods and services. The business environment related factors showed a significant and positive influence on the economic freedom of a country, trade freedom and business freedom on the import of goods and services. Thus, countries with higher economic freedom, business freedom and trade freedom could increase the import of goods and services.

\subsection{Regression Results Exports}

Table 4. Regression results exports

\begin{tabular}{|c|c|c|c|}
\hline EXP_GDP & $\begin{array}{r}\text { (Model-1) } \\
\text { Pool Effect } \\
\end{array}$ & $\begin{array}{c}\text { (Model-2) } \\
\text { Random Effect }\end{array}$ & $\begin{array}{r}\text { (Model-3) } \\
\text { Fixed Effect } \\
\end{array}$ \\
\hline Internal conflicts & $\begin{array}{c}-0.278^{* *} \\
(0.109)\end{array}$ & $\begin{array}{c}-0.080^{* *} \\
(0.032)\end{array}$ & $\begin{array}{c}-0.084 * * * \\
(0.032)\end{array}$ \\
\hline External conflicts & $\begin{array}{c}1.276 * * * \\
(0.111)\end{array}$ & $\begin{array}{c}-0.119 * * \\
(0.044)\end{array}$ & $\begin{array}{c}-0.093 * * \\
(0.044)\end{array}$ \\
\hline Gdp growth & $\begin{array}{c}0.331 \\
(0.239)\end{array}$ & $\begin{array}{c}0.203 * * * \\
(0.043)\end{array}$ & $\begin{array}{c}0.206^{* * * *} \\
(0.042)\end{array}$ \\
\hline Inflation & $\begin{array}{l}-0.128 \\
(0.106)\end{array}$ & $\begin{array}{c}0.160 * * * \\
(0.033)\end{array}$ & $\begin{array}{c}0.168 * * * \\
(0.033)\end{array}$ \\
\hline Reserve & $\begin{array}{c}0.089 \\
(0.193)\end{array}$ & $\begin{array}{c}0.1000 * * \\
(0.401)\end{array}$ & $\begin{array}{c}0.203 * * \\
(0.103)\end{array}$ \\
\hline gcf_gdp & $\begin{array}{c}0.185 * * \\
(0.078)\end{array}$ & $\begin{array}{c}0.087 * * \\
(0.039)\end{array}$ & $\begin{array}{c}0.082 * * \\
(0.039)\end{array}$ \\
\hline Interest rate & $\begin{array}{c}-0.768 * * * \\
(0.080)\end{array}$ & $\begin{array}{l}-0.004 \\
(0.101)\end{array}$ & $\begin{array}{l}-0.053 \\
(0.103)\end{array}$ \\
\hline Employment rate & $\begin{array}{c}0.006 * * * \\
(0.002)\end{array}$ & $\begin{array}{c}0.005 * * * \\
(0.002)\end{array}$ & $\begin{array}{l}0.005 * * * \\
(0.002)\end{array}$ \\
\hline Economic freedom index & $\begin{array}{c}1.053 * * * \\
(0.221)\end{array}$ & $\begin{array}{c}0.181 * * \\
(0.090)\end{array}$ & $\begin{array}{c}-0.234 * * \\
(0.115)\end{array}$ \\
\hline Tax & $\begin{array}{c}-0.523 * * * \\
(0.098)\end{array}$ & $\begin{array}{l}0.108 * * \\
(0.051)\end{array}$ & $\begin{array}{c}0.153 * * \\
(0.049)\end{array}$ \\
\hline Trade freedom & $\begin{array}{c}0.336 * * * \\
(0.113)\end{array}$ & $\begin{array}{c}0.059 * * \\
(0.029)\end{array}$ & $\begin{array}{c}0.083 * * \\
(0.038)\end{array}$ \\
\hline Business freedom & $\begin{array}{c}0.036 * * \\
(0.016)\end{array}$ & $\begin{array}{c}0.097 * * * \\
(0.049)\end{array}$ & $\begin{array}{c}0.099 * * \\
(0.049)\end{array}$ \\
\hline Exports(t-1) & $\begin{array}{c}0.385 * * * \\
(0.071)\end{array}$ & $\begin{array}{c}0.317 * * * \\
(0.041)\end{array}$ & $\begin{array}{c}0.382 * * * \\
(0.035)\end{array}$ \\
\hline _cons & $\begin{array}{c}-4.606 * * * \\
(0.393)\end{array}$ & $\begin{array}{c}0.013 \\
(0.233)\end{array}$ & $\begin{array}{c}0.371 \\
(0.237)\end{array}$ \\
\hline Obs. & 1485 & 1485 & 1485 \\
\hline R-squared & 0.238 & 0.347 & 0.362 \\
\hline
\end{tabular}

Standard errors are in parenthesis $* * * \mathrm{p}<0.01, * * \mathrm{p}<0.05, * \mathrm{p}<0.1$.

Souce author: STATA.

Table 4 represents the results for the exports to GDP as a dependent variable. While the explanatory variables considered are internal conflicts and external conflicts as main variables of interest. Moreover, control variables include other explanatory variables such as GDP growth, inflation rate, gross capital formation to GDP, interest rate, employment rate as country specific factors. The study also includes variables to account for the business environment related factors such as economic freedom index, tax duties on trade, trade freedom, business freedom and foreign reserves.

The Table 4 reported three different models results, where Model 1 is for pool effect, Model-2 is random effects and model-3 showed fixed effect results. For the selection of best model that fit the data well is decided on the 
basis of Hausman test which showed that its calculated value is 22.45 with p-value of 0.000 which is less than the critical value at $5 \%$ level of significance. Therefore, random effect model is preferred over the fixed effect model. Therefore, we will interpret our results based on the random effect modelling.

The results of the random effect model showed that our main variables that is internal conflicts and external conflicts have a negative as well as significant effect on the exports to GDP. Thus, countries with higher rate of internal conflicts and external conflicts will have negative influence on the exports of a country. Whereas, the external conflicts unfavourably affect the relationship between the countries that leads to create trade barriers in the form of taxes and high duties on exports of goods or services to a country. Therefore, both internal conflicts' and external conflicts' can negatively influence the exports of goods and services. These results supported by the previous studies conducted on the same area reported negative influence of the conflicts on the exports of countries as conflicts are assumed to be a real cause of economic activities disruption (Ezeoha \& Cattaneo, 2013; Calderon \& Serven, 2010; Herger et al., 2008).

In similar manner, GDP growth, inflation, gross capita formation, employment rate showed a positive and significant relationship of exports of goods and services. Thus, those countries with more GDP growth, high inflation rate, higher generation of gross capital formation and higher employment rate positively impact on exports of goods and services. But the interest rate and taxes or duties on trade have adverse effect on the exports of goods and services. The business environment related factors also showed positive influence on the economic freedom of a country, trade freedom and business freedom on the exports of goods and services. Thus, countries with higher economic freedom, more business freedom and trade freedom would have more exports of goods and services.

\subsection{Regression Results of Total Trade}

Table 5. Regression results of total trade

\begin{tabular}{|c|c|c|c|}
\hline TT_GDP & $\begin{array}{r}\text { (Model-1) } \\
\text { Pool Effect }\end{array}$ & $\begin{array}{c}\text { (Model-2) } \\
\text { Random Effect }\end{array}$ & $\begin{array}{r}\text { (Model-3) } \\
\text { Fixed Effect }\end{array}$ \\
\hline Internal conflicts & $\begin{array}{l}-0.354 * \\
(0.205)\end{array}$ & $\begin{array}{c}-0.196 * * * \\
(0.060)\end{array}$ & $\begin{array}{c}-0.201 * * * \\
(0.060)\end{array}$ \\
\hline External conflicts & $\begin{array}{c}-2.314 * * * \\
(0.204)\end{array}$ & $\begin{array}{c}-0.401 * * \\
(0.201)\end{array}$ & $\begin{array}{c}-0.1670 * * \\
(0.801)\end{array}$ \\
\hline Gdp growth & $\begin{array}{c}0.440 \\
(0.504)\end{array}$ & $\begin{array}{c}0.264 * * * \\
(0.080)\end{array}$ & $\begin{array}{c}0.272 * * * \\
(0.079)\end{array}$ \\
\hline Inflation & $\begin{array}{c}-0.388 * * \\
(0.198)\end{array}$ & $\begin{array}{l}0.146 * * \\
(0.061)\end{array}$ & $\begin{array}{c}0.160 * * * \\
(0.061)\end{array}$ \\
\hline Reserve & $\begin{array}{l}0.868^{* *} \\
(0.400)\end{array}$ & $\begin{array}{l}-0.601 * * \\
(0.301)\end{array}$ & $\begin{array}{l}-0.271 * * \\
(0.0192)\end{array}$ \\
\hline gcf_gdp & $\begin{array}{c}0.734 * * * * \\
(0.145)\end{array}$ & $\begin{array}{c}0.689 * * * \\
(0.073)\end{array}$ & $\begin{array}{c}0.684 * * * \\
(0.072)\end{array}$ \\
\hline Interest rate & $\begin{array}{c}-1.091^{* * *} \\
(0.151)\end{array}$ & $\begin{array}{c}-0.206^{* *} \\
(0.101)\end{array}$ & $\begin{array}{c}-0.443 * * \\
(0.222)\end{array}$ \\
\hline Employment rate & $\begin{array}{l}0.007 * \\
(0.004)\end{array}$ & $\begin{array}{c}0.009 * * * \\
(0.003)\end{array}$ & $\begin{array}{c}0.009 * * * \\
(0.003)\end{array}$ \\
\hline Economic freedom index & $\begin{array}{c}1.648^{* * * *} \\
(0.423)\end{array}$ & $\begin{array}{l}-0.022 \\
(0.244)\end{array}$ & $\begin{array}{l}-0.339 \\
(0.252)\end{array}$ \\
\hline Tax & $\begin{array}{c}-1.061 * * * \\
(0.188)\end{array}$ & $\begin{array}{l}-0.281^{*} \\
(0.170)\end{array}$ & $\begin{array}{c}-0.356 * * \\
(0.176)\end{array}$ \\
\hline Trade freedom & $\begin{array}{l}0.621 * * * \\
(0.211)\end{array}$ & $\begin{array}{c}0.841 * * * \\
(0.209)\end{array}$ & $\begin{array}{l}0.881 * * * \\
(0.209)\end{array}$ \\
\hline Business freedom & $\begin{array}{c}0.251 * * \\
(0.105)\end{array}$ & $\begin{array}{c}0.541 * * * \\
(0.092)\end{array}$ & $\begin{array}{c}0.431 * * * \\
(0.092)\end{array}$ \\
\hline TTrade $(\mathrm{t}-1)$ & $\begin{array}{l}0.474 * * * \\
(0.145)\end{array}$ & $\begin{array}{l}0.419 * * * \\
(0.073)\end{array}$ & $\begin{array}{c}0.417 * * * \\
(0.072)\end{array}$ \\
\hline _cons & $\begin{array}{c}-7.916^{* * *} \\
(0.756)\end{array}$ & $\begin{array}{c}0.107 \\
(0.435)\end{array}$ & $\begin{array}{c}0.673 \\
(0.443)\end{array}$ \\
\hline Obs. & 1485 & 1485 & 1485 \\
\hline $\begin{array}{l}\text { R-squared } \\
\text { Hausman Statistics }\end{array}$ & 0.224 & 0.261 & $\begin{array}{c}0.273 \\
22.14(0.000)\end{array}$ \\
\hline
\end{tabular}

Standard errors are in parenthesis $* * * \mathrm{p}<0.01, * * \mathrm{p}<0.05, * \mathrm{p}<0.1$.

Souce author: STATA. 
Table 5 represents the results for the total trade to GDP as a dependent variable. Whereas, the independent variables include internal conflicts and external conflicts as a variable of interest. Moreover, other explanatory variables include GDP growth, inflation rate, gross capital formation to GDP, interest rate, employment rate as country specific factors. The study also includes business environment related factors such as foreign reserves, economic freedom index, tax duties on trade, trade freedom and business freedom. The Table 5 showed results of three models that is Model 1 showed results of pool effect, Model-2 showed results of random effects and model-3 represent results of fixed effect model. For the selection of best model that fit the data well is decided on the basis of Hausman test which showed that its calculated value is 22.14 with p-value of 0.000 which is less than the critical value at $5 \%$ level of significance. Therefore, random effect model is preferred over the fixed effect model. Therefore, we will interpret our results based on the random effect modelling.

The results of the random effect model showed that internal conflicts and external conflicts have a negative and significant impact on the total trade to GDP. So, countries with higher rate of internal conflicts and external conflicts will have negative influence on their international trade with the trading partners. It is due to the fact that internal conflicts rescind the local industry and reduces the purchasing power of the people that could reduce their spending on goods. Whereas, the external conflicts also isolate a country from other trading partners that could adversely affect the relationship between the countries that leads to create trade barriers in the form of taxes and high duties on international trade. Therefore, both internal conflicts' as well as external conflicts' can negatively affect the international trade of a country. These results are supported by previous studies which also suggested that total trade of a country is negatively associated with the level of internal and external conflicts prevailing in a country Anderson and Marcouiller, (2002); Blomberg and Hess (2006); Chang, Polachek and Robst (2004) and Görg, Meyer, and de-Rosa (2013).

The results of the control variables like GDP growth, inflation, gross capita formation, employment rate are found to have a positive and significant influence on the international trade. Thus, countries with future prospects for GDP growth, high inflation rate, more gross capital formation and higher employment rate could have a positive effect on international trade. However, interest rate and taxes or duties on trade could reduce international trade. The business environment related factors also showed a positive influence on the economic freedom of a country, trade freedom and business freedom on the international trade. Thus, countries with higher economic freedom, business freedom and trade freedom could increase their international trade with the trading partners and improve the overall economic growth in the region.

\subsection{Regression Results of Economic growth}

Table 6. Regression results of economic growth

\begin{tabular}{|c|c|c|c|}
\hline Economic growth & $\begin{array}{l}\text { (Model-1) } \\
\text { Pool Effect } \\
\end{array}$ & $\begin{array}{c}\text { (Model-2) } \\
\text { Random Effect } \\
\end{array}$ & $\begin{array}{l}\text { (Model-3) } \\
\text { Fixed Effect }\end{array}$ \\
\hline Internal conflicts & $\begin{array}{c}-0.091 * * * \\
(0.018)\end{array}$ & $\begin{array}{c}-0.086 * * * \\
(0.018)\end{array}$ & $\begin{array}{c}-0.068 * * * \\
(0.020)\end{array}$ \\
\hline External conflicts & $\begin{array}{c}-0.070 * * \\
(0.031)\end{array}$ & $\begin{array}{c}-0.091 * * * \\
(0.031)\end{array}$ & $\begin{array}{c}-0.134 * * \\
(0.060)\end{array}$ \\
\hline Export_gdp & $\begin{array}{c}0.011 \\
(0.011)\end{array}$ & $\begin{array}{c}0.014 * * \\
(0.006)\end{array}$ & $\begin{array}{c}0.084 * * * \\
(0.017)\end{array}$ \\
\hline Import_gdp & $\begin{array}{c}-0.004 * * \\
(0.002)\end{array}$ & $\begin{array}{c}-0.005 * * \\
(0.002)\end{array}$ & $\begin{array}{c}-0.008 * * * \\
(0.001)\end{array}$ \\
\hline Inflation & $\begin{array}{l}0.060^{* * *} \\
(0.026)\end{array}$ & $\begin{array}{c}0.055^{* * * *} \\
(0.020)\end{array}$ & $\begin{array}{c}0.006 \\
(0.021)\end{array}$ \\
\hline Foreign Reserve & $\begin{array}{c}0.059 \\
(0.138)\end{array}$ & $\begin{array}{l}0.088 * * * \\
(0.028)\end{array}$ & $\begin{array}{l}0.679 * * * \\
(0.063)\end{array}$ \\
\hline GCF_GDP & $\begin{array}{c}0.106 * * * \\
(0.036)\end{array}$ & $\begin{array}{c}0.108 * * * \\
(0.018)\end{array}$ & $\begin{array}{c}0.116^{* * * *} \\
(0.025)\end{array}$ \\
\hline Interest & $\begin{array}{l}-0.039^{*} \\
(0.020)\end{array}$ & $\begin{array}{c}-0.049 * * \\
(0.022)\end{array}$ & $\begin{array}{l}-0.071 \\
(0.065)\end{array}$ \\
\hline Employment & $\begin{array}{l}-0.001 \\
(0.000)\end{array}$ & $\begin{array}{l}0.003 * * \\
(0.001)\end{array}$ & $\begin{array}{l}0.002 * \\
(0.001)\end{array}$ \\
\hline Economic freedom index & $\begin{array}{c}0.099 \\
(0.080)\end{array}$ & $\begin{array}{l}0.158 * * * \\
(0.040)\end{array}$ & $\begin{array}{l}0.393 * * * \\
(0.085)\end{array}$ \\
\hline Tax Burden & $\begin{array}{c}0.039 \\
(0.041)\end{array}$ & $\begin{array}{c}0.034 * * * \\
(0.012)\end{array}$ & $\begin{array}{l}0.281 * * * * \\
(0.060)\end{array}$ \\
\hline
\end{tabular}




\begin{tabular}{|c|c|c|c|}
\hline Trade freedom & $\begin{array}{c}0.028 \\
(0.035)\end{array}$ & $\begin{array}{c}0.046 * * \\
(0.022)\end{array}$ & $\begin{array}{c}0.142 * * * \\
(0.037)\end{array}$ \\
\hline Business freedom & $\begin{array}{l}-0.014 \\
(0.028)\end{array}$ & $\begin{array}{c}0.041^{* *} \\
(0.020)\end{array}$ & $\begin{array}{r}0.185^{* * * *} \\
(0.031)\end{array}$ \\
\hline _cons & $\begin{array}{c}0.037 \\
(0.173)\end{array}$ & $\begin{array}{c}0.067 \\
(0.067)\end{array}$ & $\begin{array}{c}0.427 \text { *** } \\
(0.151)\end{array}$ \\
\hline Obs. & 1485 & 1485 & 1485 \\
\hline R-squared & 0.099 & 0.165 & 0.172 \\
\hline Hausman Statistics & \multicolumn{3}{|c|}{$25.65(0.000)$} \\
\hline
\end{tabular}

Standard errors are in parenthesis $* * * \mathrm{p}<0.01, * * \mathrm{p}<0.05, * \mathrm{p}<0.1$.

Souce author: STATA.

Table 6 represents results of the regression models that are estimated with the aim to test the hypothesis of effect of internal and external conflicts on the economic growth of a country. Therefore, the study considered economic growth as measured through GDP growth and also take in to account the main explanatory variables such as internal conflicts and external conflicts. Moreover, the study also assumed control variables of country specific factors such as capital formation, employment rate, interest rate, foreign reserves, imports and exports. Moreover, the business environment variables include economic freedom, trade freedom and business freedom.

The results reported in Table 6 for regression Model-1, Model-2 and Model-3 represents pool effect, random effect and fixed effect regression models respectively. The results of the Hausman test are used to decide among the three mentioned models that could better fit the data. The results of the Hausman test showed that the Hausman test significant value i.e. 25.65(0.000) is more than the critical value and its p-value is less than 5percent. Thus, random effect modelling could better fit the data relative of the other two. Therefore, the results of the random effect will be interpreted only.

The results of the random effect regression model showed that internal conflicts and external conflicts have negative and significant effect on the economic growth of a country. Therefore, countries with more internal or external conflicts have adverse effect on the economic growth of a country. Therefore, the policymakers and the government may focus on such strategies to reduce internal as well as external conflicts only than they would be able to put themselves on the road of economic growth. It is pertinent to mentioned that most of the countries with internal and external conflicts can have a very low economic growth and poor wellbeing of the general public. So, if the political leadership may succeed in managing conflicts could make it possible to progress. This negative effect of conflicts and economic growth is also supported by previous studies such as Cowan and Neut, (2007); Martin, Mayer, and Thoenig (2008); Afaq and Khan (2016) and Byrne and Fiess (2015).

The estimates of other variables such as exports are found to have a positive and significant influence on the economic growth of a country, whereas, the imports are found significant but with negative effect on the economic growth of a country. Thus, increase in exports and decreases in imports could also improve economic growth of a country. However, this could only be true for the high-level imports as optimal imports are expected to have no adverse effect on the economic growth. Furthermore, no country is self-sufficient in all goods or services and they do import so goods or services, however, these results could be attributed to a situation where more imports if done that could harm the economic growth through various channels.

The results of other control variables such as country specific factors including gross capital formation, inflation rate, employment rate and foreign reserves have a positive and significant impact on the economic growth of countries. So, higher level of capital formation, more employment rate, and higher inflation rate could lead to economic growth of a country. However, higher level of interest rate has negative and significant influence on the economic growth of a country. Thus, countries with higher interest rate could have a negative economic growth.

The results of business environment related variables showed that economic freedom, business freedom and trade freedom have positive and significant influence on the on the country economic growth. Therefore, it can be concluded that countries with more economic freedom, trade and business freedom could be able to have relatively high economic growth which would leads to more economic prosperity.

Now to check for the incremental effect of GDP growth, employment rate, economic freedom index, trade freedom and business freedom in between the internal conflicts and external conflicts on the total trade. For this purpose, the study has used interaction variables of internal and external conflicts with of GDP growth, employment rate, economic freedom index, trade freedom and business freedom. Table 7 represents results of the fixed effect regression models with the dependent variable as total trade and the explanatory variables include 
internal and external conflicts and their interaction terms with GDP growth, employment rate, economic freedom index, trade freedom and business freedom. The results also include other control variables of the baseline regression model.

The results of various estimated models showed that internal and external conflicts have negative and significant effect on the total trade to GDP. These results imply that internal and external conflicts have adverse effect on a country trade. The estimated results showed that the coefficients of interaction of internal and external conflict with GDP growth are positive and significant with total trade. The positive coefficient of interaction terms of conflicts with GDP growth showed that GDP growth will minimize the negative effect of internal and external conflicts on total trade. Thus, GDP growth positively moderate the effect of conflicts on total trade. Therefore, countries with emergent conflicts required to focus on their GDP growth rate which would mitigate the negative effect of conflicts on trade.

The economic freedom index interactions with internal and external conflicts have positive coefficients with trade. These results also suggested that increase in economic freedom would trade off negative effects of internal and external conflicts on country trade. This could be due to the fact that economic activities within a country and across different countries could create peace and harmony within and across countries. Similar, results are found in case of trade freedom and business freedom interactions with internal and external conflicts. These results also imply that trade and business freedom promote peace in the region and masses will focused on the business and economic activities which could significantly mitigate the negative effects of conflicts on trade.

The coefficients of interaction variables of employment rate with internal conflicts showed that there is a positive and significant effect of employment rate interactions on trade whereas, there is insignificant effect of GDP growth interaction external conflicts. Thus, countries with a higher employment rate could mitigate the negative effect of internal conflicts on trade of a country, however, external conflicts cannot vary with level of employment rate. Moreover, the results of other control variables are consistent with the baseline estimated results reported in table 5 .

\subsection{Regression Results of Interaction Effects}

Table 7. Regression results of interaction effects

\begin{tabular}{|c|c|c|c|c|c|}
\hline TT_GDP & $\begin{array}{c}\text { (Model-1) } \\
\text { GDP }\end{array}$ & $\begin{array}{c}\text { (Model-2) } \\
\text { EFI }\end{array}$ & $\begin{array}{c}\text { (Model-3) } \\
\text { EMPRate }\end{array}$ & $\begin{array}{c}\text { (Model-4) } \\
\text { TFreedom }\end{array}$ & $\begin{array}{r}\text { (Model-5) } \\
\text { BFreedom }\end{array}$ \\
\hline Internal conflicts & $\begin{array}{c}-0.754 * * * \\
(0.009)\end{array}$ & $\begin{array}{c}-0.764 * * * \\
(0.009)\end{array}$ & $\begin{array}{c}-0.735^{* * * *} \\
(0.009)\end{array}$ & $\begin{array}{c}-0.763 * * * \\
(0.009)\end{array}$ & $\begin{array}{c}-0.794 * * * \\
(0.009)\end{array}$ \\
\hline External conflicts & $\begin{array}{c}-0.256 * * * \\
(0.020)\end{array}$ & $\begin{array}{c}-0.297 * * * \\
(0.020)\end{array}$ & $\begin{array}{c}-0.274 * * * \\
(0.020)\end{array}$ & $\begin{array}{c}-0.246 * * * \\
(0.020)\end{array}$ & $\begin{array}{c}-0.291 * * * \\
(0.020)\end{array}$ \\
\hline Gdp_Internal conflicts & $\begin{array}{l}0.091 * * * \\
(0.032)\end{array}$ & & & & \\
\hline Gdp_External conflicts & $\begin{array}{l}0.041 * * * \\
(0.012)\end{array}$ & & & & \\
\hline EFI_Internal Conflicts & & $\begin{array}{c}0.392 * * \\
(0.192)\end{array}$ & & & \\
\hline EFI_External Conflicts & & $\begin{array}{c}0.205 * * * \\
(0.092)\end{array}$ & & & \\
\hline EmpRate_Internal Conflicts & & & $\begin{array}{c}0.003 * * * \\
(0.001)\end{array}$ & & \\
\hline EmpRate_External Conflicts & & & $\begin{array}{l}0.003 * \\
(0.002)\end{array}$ & & \\
\hline TFreedom_Internal Conflicts & & & & $\begin{array}{c}0.463 * * * \\
(0.126)\end{array}$ & \\
\hline TFreedom_External Conflicts & & & & $\begin{array}{c}0.163 * * * \\
(0.026)\end{array}$ & \\
\hline BFreedom_Internal Conflicts & & & & & $\begin{array}{l}0.611 * * * \\
(0.106)\end{array}$ \\
\hline BFreedom_External Conflicts & & & & & $\begin{array}{l}0.211 * \\
(0.111)\end{array}$ \\
\hline Gdp growth & $\begin{array}{c}0.212 * * * \\
(0.079)\end{array}$ & $\begin{array}{c}0.292 * * * \\
(0.079)\end{array}$ & $\begin{array}{c}0.272 * * * \\
(0.079)\end{array}$ & $\begin{array}{c}0.261 * * * \\
(0.079)\end{array}$ & $\begin{array}{c}0.252 * * * \\
(0.079)\end{array}$ \\
\hline Reserve & $\begin{array}{c}0.160 * * * \\
(0.061)\end{array}$ & $\begin{array}{c}0.160 * * * \\
(0.061) \\
\end{array}$ & $\begin{array}{c}0.160 * * * \\
(0.061) \\
\end{array}$ & $\begin{array}{c}0.160 * * * \\
(0.061) \\
\end{array}$ & $\begin{array}{c}0.160 * * * \\
(0.061)\end{array}$ \\
\hline
\end{tabular}




\begin{tabular}{|c|c|c|c|c|c|}
\hline \multirow[t]{2}{*}{ gcf_gdp } & $-0.271 * *$ & $-0.271^{* *}$ & $-0.271 * *$ & $-0.271^{* *}$ & $-0.271 * *$ \\
\hline & $(0.0192)$ & $(0.0192)$ & $(0.0192)$ & $(0.0192)$ & $(0.0192)$ \\
\hline \multirow[t]{2}{*}{ Interest rate } & $0.684 * * *$ & $0.684 * * *$ & $0.684 * * *$ & $0.684 * * *$ & $0.684 * * *$ \\
\hline & $(0.072)$ & $(0.072)$ & $(0.072)$ & $(0.072)$ & $(0.072)$ \\
\hline \multirow[t]{2}{*}{ Employment rate } & $-0.443 * *$ & $-0.433^{* *}$ & $-0.313^{* *}$ & $-0.413^{* *}$ & $-0.423 * *$ \\
\hline & $(0.222)$ & $(0.122)$ & $(0.222)$ & $(0.222)$ & $(0.222)$ \\
\hline \multirow[t]{2}{*}{ Economic freedom index } & $0.009 * * *$ & $0.007 * * *$ & $0.009 * * *$ & $0.009 * * *$ & $0.009 * * *$ \\
\hline & $(0.003)$ & $(0.003)$ & $(0.003)$ & $(0.003)$ & $(0.003)$ \\
\hline \multirow[t]{2}{*}{ Tax } & -0.339 & -0.339 & -0.339 & -0.339 & -0.339 \\
\hline & $(0.252)$ & $(0.252)$ & $(0.252)$ & $(0.252)$ & $(0.252)$ \\
\hline \multirow{2}{*}{ Trade freedom } & $-0.356^{* *}$ & $-0.356^{* *}$ & $-0.356^{* *} *$ & $-0.315^{* *}$ & $-0.356^{* *}$ \\
\hline & $(0.176)$ & $(0.176)$ & $(0.176)$ & $(0.151)$ & $(0.176)$ \\
\hline \multirow[t]{2}{*}{ Business freedom } & $0.841 * * *$ & $0.841 * * *$ & $0.851^{* * *}$ & $0.871^{* * *} *$ & $0.481 * * *$ \\
\hline & $(0.209)$ & $(0.209)$ & $(0.209)$ & $(0.209)$ & $(0.119)$ \\
\hline \multirow[t]{2}{*}{ _cons } & $0.465 * * *$ & $0.493 * * *$ & $0.485^{* * *}$ & $0.453 * * *$ & $0.404^{* * *}$ \\
\hline & $(0.091)$ & $(0.090)$ & $(0.091)$ & $(0.094)$ & $(0.094)$ \\
\hline Obs. & 1485 & 1485 & 1485 & 1485 & 1485 \\
\hline R-squared & 0.234 & 0.213 & 0.243 & 0.253 & 0.233 \\
\hline Hausman test & $24.43(0.000)$ & $27.13(0.000)$ & $21.21(0.000)$ & $29.54(0.000)$ & $26.54(0.000)$ \\
\hline
\end{tabular}

Standard errors are in parenthesis $* * * \mathrm{p}<0.01, * * \mathrm{p}<0.05, * \mathrm{p}<0.1$.

Souce author: STATA.

Similarly, to check for the incremental effect of total trade, employment rate, economic freedom index, trade freedom and business freedom in between the internal conflicts and external conflicts on the economic growth of a country. This study has used interaction variables of internal and external conflicts with of total trade, employment rate, economic freedom index, trade freedom and business freedom.

Table 8 represents results of the fixed effect regression models with the dependent variable as economic growth and the explanatory variables include internal and external conflicts and their interaction terms with total trade, employment rate, economic freedom index, trade freedom and business freedom. The results also include other control variables of the baseline regression model.

The results of various estimated fixed effect models showed that internal and external conflicts have negative and significant effect on economic growth of a country. These results showed that increase in internal and external conflicts will have adverse effect on a country economic growth. These conflicts are considered as hurdles on the way of trade and constrained economic activates and overall growth. The estimated results showed that the coefficients of interactions of internal and external conflict with trade are positive and significantly influencing the economic growth of a country. The positive coefficients of interaction of conflicts with trade showed that increase in trade activities within the country and with other neighbours could minimize the negative effect of internal and external conflicts on total trade. Thus, GDP growth positively moderate the effect of conflicts on total trade. Therefore, countries with emergent conflicts required to focus on their GDP growth rate which would mitigate the negative effect of conflicts on trade.

The economic freedom index interactions with internal and external conflicts have positive coefficients with trade. These results also suggested that increase in economic freedom would trade off negative effects of internal and external conflicts on country trade. This could be due to the fact that economic activities within a country and across different countries could create peace and harmony within and across countries. Similar, results are found in case of trade freedom and business freedom interactions with internal and external conflicts. These results also imply that trade and business freedom promote peace in the region and masses will focused on the business and economic activities which could significantly mitigate the negative effects of conflicts on trade.

The coefficients of interaction variables of employment rate with internal conflicts showed that there is a positive and significant effect of employment rate interactions on trade whereas, there is insignificant effect of GDP growth interaction external conflicts. Thus, countries with a higher employment rate could mitigate the negative effect of internal conflicts on trade of a country, however, external conflicts cannot vary with level of employment rate. Moreover, the results of other control variables are consistent with the baseline estimated results reported in table5. 
4.8 Regression Results of Economic growth

Table 8. Regression results of economic growth

\begin{tabular}{|c|c|c|c|c|c|}
\hline Economic growth & $\begin{array}{l}\text { (Model-1) } \\
\text { TT_GDP }\end{array}$ & $\begin{array}{c}\text { (Model-2) } \\
\text { EFI } \\
\end{array}$ & $\begin{array}{l}\text { (Model-3) } \\
\text { EmpRate }\end{array}$ & $\begin{array}{l}\text { (Model-4) } \\
\text { TFreedom }\end{array}$ & $\begin{array}{l}\text { (Model-5) } \\
\text { Bfreedom }\end{array}$ \\
\hline Internal conflicts & $\begin{array}{c}-0.061 * * * \\
(0.018)\end{array}$ & $\begin{array}{c}-0.068 * * * \\
(0.020)\end{array}$ & $\begin{array}{c}-0.058 * * * \\
(0.018)\end{array}$ & $\begin{array}{c}-0.063 * * * \\
(0.020)\end{array}$ & $\begin{array}{c}-0.066^{* * *} \\
(0.018)\end{array}$ \\
\hline External conflicts & $\begin{array}{c}-0.081 * * * \\
(0.021)\end{array}$ & $\begin{array}{c}-0.072 * * \\
(0.006)\end{array}$ & $\begin{array}{c}-0.071^{* * *} \\
(0.023)\end{array}$ & $\begin{array}{c}-0.095 * * \\
(0.030)\end{array}$ & $\begin{array}{c}-0.071^{* * *} \\
(0.036)\end{array}$ \\
\hline TT_Internal conflicts & $\begin{array}{c}0.071 * * * \\
(0.022)\end{array}$ & & & & \\
\hline TT_External conflicts & $\begin{array}{c}0.051 * * * \\
(0.012)\end{array}$ & & & & \\
\hline EFI_Internal Conflicts & & $\begin{array}{c}0.0192 * * \\
(0.092)\end{array}$ & & & \\
\hline EFI_External Conflicts & & $\begin{array}{c}0.0205 * * * \\
(0.002)\end{array}$ & & & \\
\hline EmpRate_Internal Conflicts & & & $\begin{array}{c}0.021 * * \\
(0.010)\end{array}$ & & \\
\hline EmpRate_External Conflicts & & & $\begin{array}{c}0.039 \\
(0.046)\end{array}$ & & \\
\hline TFreedom_Internal Conflicts & & & & $\begin{array}{c}0.046^{* * *} \\
(0.022)\end{array}$ & \\
\hline TFreedom_External Conflicts & & & & $\begin{array}{c}0.0163 * * \\
(0.071)\end{array}$ & \\
\hline BFreedom_Internal Conflicts & & & & & $\begin{array}{c}0.611 * * * \\
(0.106)\end{array}$ \\
\hline BFreedom_External Conflicts & & & & & $\begin{array}{l}0.211 * \\
(0.111)\end{array}$ \\
\hline TT_GDP & $\begin{array}{c}0.014^{* *} \\
(0.006)\end{array}$ & $\begin{array}{c}0.024^{* *} \\
(0.012)\end{array}$ & $\begin{array}{c}0.014 * * \\
(0.006)\end{array}$ & $\begin{array}{c}0.031 * * * \\
(0.012)\end{array}$ & $\begin{array}{c}0.014 * * \\
(0.006)\end{array}$ \\
\hline Inflation & $\begin{array}{c}0.055^{* * * *} \\
(0.020)\end{array}$ & $\begin{array}{c}0.006 \\
(0.021)\end{array}$ & $\begin{array}{c}0.055^{* * * *} \\
(0.020)\end{array}$ & $\begin{array}{c}0.006 \\
(0.021)\end{array}$ & $\begin{array}{c}0.055 * * * \\
(0.020)\end{array}$ \\
\hline Foreign Reserve & $\begin{array}{c}0.088^{* * * *} \\
(0.028)\end{array}$ & $\begin{array}{c}0.679 * * * \\
(0.063)\end{array}$ & $\begin{array}{c}0.088^{* * * *} \\
(0.028)\end{array}$ & $\begin{array}{c}0.679 * * * \\
(0.063)\end{array}$ & $\begin{array}{c}0.088^{* * * *} \\
(0.028)\end{array}$ \\
\hline GCF_GDP & $\begin{array}{c}0.108^{* * *} * \\
(0.018)\end{array}$ & $\begin{array}{c}0.116^{* * * *} \\
(0.025)\end{array}$ & $\begin{array}{c}0.108 * * * \\
(0.018)\end{array}$ & $\begin{array}{c}0.116^{* * *} \\
(0.025)\end{array}$ & $\begin{array}{c}0.108^{* * * *} \\
(0.018)\end{array}$ \\
\hline Interest & $\begin{array}{c}-0.049 * * \\
(0.022)\end{array}$ & $\begin{array}{l}-0.071 \\
(0.065)\end{array}$ & $\begin{array}{c}-0.049 * * \\
(0.022)\end{array}$ & $\begin{array}{l}-0.071 \\
(0.065)\end{array}$ & $\begin{array}{c}-0.049 * * \\
(0.022)\end{array}$ \\
\hline Employment & $\begin{array}{c}0.003^{* *} \\
(0.001)\end{array}$ & $\begin{array}{l}0.002 * \\
(0.001)\end{array}$ & $\begin{array}{c}0.003 * * \\
(0.001)\end{array}$ & $\begin{array}{l}0.002 * \\
(0.001)\end{array}$ & $\begin{array}{c}0.003 * * \\
(0.001)\end{array}$ \\
\hline Economic freedom index & $\begin{array}{c}0.158 * * * \\
(0.040)\end{array}$ & $\begin{array}{c}0.393 * * * \\
(0.085)\end{array}$ & $\begin{array}{c}0.158 * * * \\
(0.040)\end{array}$ & $\begin{array}{c}0.393 * * * \\
0.085)\end{array}$ & $\begin{array}{c}0.158 * * * \\
(0.040)\end{array}$ \\
\hline Tax Burden & $\begin{array}{c}0.034 * * * \\
(0.012)\end{array}$ & $\begin{array}{c}0.281 * * * \\
(0.060)\end{array}$ & $\begin{array}{c}0.034 * * * \\
(0.012)\end{array}$ & $\begin{array}{c}0.281 * * * \\
(0.060)\end{array}$ & $\begin{array}{c}0.034 * * * \\
(0.012)\end{array}$ \\
\hline Trade freedom & $\begin{array}{c}0.046^{* *} \\
(0.022)\end{array}$ & $\begin{array}{c}0.142 * * * \\
(0.037)\end{array}$ & $\begin{array}{c}0.046^{* *} \\
(0.022)\end{array}$ & $\begin{array}{c}0.142 * * * \\
(0.037)\end{array}$ & $\begin{array}{c}0.046^{* *} \\
(0.022)\end{array}$ \\
\hline Business freedom & $\begin{array}{c}0.041^{* *} \\
(0.020)\end{array}$ & $\begin{array}{c}0.185^{* * * *} \\
(0.031)\end{array}$ & $\begin{array}{c}0.041^{* *} \\
(0.020)\end{array}$ & $\begin{array}{c}0.185^{* * * *} \\
(0.031)\end{array}$ & $\begin{array}{c}0.041^{* *} \\
(0.020)\end{array}$ \\
\hline _cons & $\begin{array}{c}0.067 \\
(0.067)\end{array}$ & $\begin{array}{c}0.427 * * * \\
(0.151)\end{array}$ & $\begin{array}{c}0.067 \\
(0.067)\end{array}$ & $\begin{array}{c}0.427 * * * \\
(0.151)\end{array}$ & $\begin{array}{c}0.067 \\
(0.067)\end{array}$ \\
\hline Obs. & 1485 & 1485 & 1485 & 1485 & 1485 \\
\hline R-squared & 0.165 & 0.172 & 0.165 & 0.172 & 0.165 \\
\hline Hausman Statistics & $34.65(0.000)$ & $35.55(0.000)$ & $35.05(0.000)$ & $32.61(0.000)$ & $39.46(0.000)$ \\
\hline
\end{tabular}

Standard errors are in parenthesis $* * * \mathrm{p}<0.01, * * \mathrm{p}<0.05, * \mathrm{p}<0.1$.

Souce author: STATA. 


\section{Conclusion}

This study examines the impact of internal and external conflicts on the economic growth of countries. The study used 128 countries for the estimation with data collected from the World Bank for the period 1996 and 2016 and using the Hausman test. The regression results show that internal conflicts and external conflicts negatively affect the economic growth of a country. Therefore, this work has argued that internal and external conflicts play a vital role in reducing the country's overall trade, imports and exports. Moreover, these conflicts have a devastating effect on the economic growth of these countries.

\subsection{Recommendations}

For the improvement of international trade and economic prosperity the countries are required to be devised such policies that could constrained the internal and external conflicts and which could only be possible to bring economic growth in a country.

\subsection{Limitations of the Study}

This study does not aim to answer or deal with all the questions concerning the effect of the internal and external conflicts on the economic growth.

One of the limitation of this study is due to the small sample size of the study period included in the data sample. For example, this study only covers a 21 years' period from 1996 to 2016, leading to certain limitations in the total validation of our study because of the small sample size.

\subsection{Areas for Further Research}

Several other questions remain open for further studies with the construction of other variables that can better represent and empirically explain the impact of external conflict in a larger dimension. Other econometric techniques can be used to solve this problem at all levels. Extending the use of other empirical tests on a complementary basis would go a long way to solving the problem; such as, for example, cross-sectional estimation, analysis by the method of cointegration (to detect trends in the relationship between external conflicts and long-term economic growth). The theme of the question, which has not been studied in depth in this work, deserves to be integrated into the methods which have not been cited to better detect the impact of external conflict on economic growth.

\section{References}

Agarwal, J. P. (1980). Determinants of Foreign Direct Investment: A Survey. Review of World Economics, 116(4), 739-773. https://doi.org/10.1007/BF02696547

Aizenman, J., \& Reuven, G. (2006). Military Expenditure, Threats, and Growth. The Journal of International Trade \& Economic Development, 15(2), 129-155. https://doi.org/10.1080/09638190600689095

Aker, J. C. (2008). Rainfall shocks, markets, and food crises: Evidence from the Sahel. Center for Global Development Working Paper, (157). https://doi.org/10.2139/ssrn.1321846

Ali, F. A., Norbert, F., \& Ronald, M. (2010). Do Institutions Matter for Foreign Direct Investment? Open Economies Review, 21(2), 201-19. https://doi.org/10.1007/s11079-010-9170-4

Andersson, F. N. G. (2008). Wavelet analysis of economic time series. Lund Economic Studies, 149.

Andersson, F. N. G. (2016). Identifying and Modelling Cycles and Long Waves in Economic Time Series.” In J. Ljungberg (Ed.), Structural Analysis and the Process of Economic Development (pp. 34-55). New York: Routledge. https://lup.lub.lu.se/record/7933444c-c92a-48d0-8284-55ac22add37b

Andersson, F. N. G., David, E., \& Sonja, O. (2013). A Matter of Time: Revisiting Growth Convergence in China. World Development, 45, 239-251. https://doi.org/10.1016/j.worlddev.2012.12.013

Asiedu, E. (2002). On the Determinants of Foreign Direct Investment to Developing Countries: Is Africa Different? World Development, 30(1), 107-19. https://doi.org/10.1016/S0305-750X(01)00100-0

Asiedu, E. (2006). Foreign Direct Investment in Africa: The Role of Natural Resources, Market Size, Government Policy, Institutions and Political Instability. The World Economy, 29(1), 63-77. https://doi.org/10.1111/j.1467-9701.2006.00758.x

Aziz, M. N., \& Asadullah, M. N. (2017). Military Spending, Armed Conflict and Economic Growth in Developing countries in the Post-Cold War era. Journal of Economic Studies, 44(1), 47-68. https://doi.org/10.1108/JES-01-2015-0021

Barro, R. J., \& Sala-i-Martin, X. (2004). Economic Growth (2nd ed.). Cambridge, MA: The MIT Press. 
Baum, F. C., Mark, E. S., \& Steven, S. (2007). Enhanced Routines for Instrumental Variables/Generalized Method of Moments Estimation and Testing. The Stata Journal, 7(4), 465-506. https://doi.org/10.1177/1536867X0800700402

Benoit, E. (1978). Growth and Defense in Developing Countries. Economic Development and Cultural Change, 26(2), 271-280. https://doi.org/10.1086/451015

Berman, N., \& Couttenier, M. (2015). External shocks, internal shots: The geography of civil conflicts. Review of Economics \& Statistics, 97(4), 758-776. https://doi.org/10.1162/REST_a_00521

Besley, T., \& Persson, T. (2008). Wars and state capacity. Journal of the European Economic Association, 6(2-3), 522-530. https://doi.org/10.1162/JEEA.2008.6.2-3.522

Blainey, G. (1973). Causes of war (3rd ed.). New York: Free Press. https://doi.org/10.1007/978-1-349-01690-7

Blomberg, S. B., \& Hess, G. D. (2005). The lexus and the olive branch: Globalization, democratization, and terrorism. https://doi.org/10.2139/ssrn.904024

Blonigen, B. (2005). A Review of the Empirical Literature on FDI Determinants. NBER Working Paper, no. 11299. Cambridge, Mass.: National Bureau of Economic Research. https://doi.org/10.1007/s11293-005-2868-9

Blundell, R., \& Stephen, B. (1998). Initial Conditions and Moment Restrictions in Dynamic Panel Data Models. Journal of Econometrics, 87(1), 115-43. https://doi.org/10.1016/S0304-4076(98)00009-8

Busse, M., \& Carsten, H. (2007). Political Risk, Institutions and Foreign Direct Investment. European Journal of Political Economy, 23(2), 397-415. https://doi.org/10.1016/j.ejpoleco.2006.02.003

Byrne, J. P., \& Fiess, N. (2016). International capital flows to emerging markets: National and global determinants. Journal of International Money and Finance, 61(C), 82-100. https://doi.org/10.1016/j.jimonfin.2015.11.005

Cothren, R. (2002). A Model of Military Spending and Economic Growth. Public Choice, 110(1/2), 121-142. https://doi.org/10.1023/A:1013049322032

Crowley, P. M. (2007). A Guide to Wavelets for Economists. Journal of Economic Surveys, 21(2), 207-267. https://doi.org/10.1111/j.1467-6419.2006.00502.x

Deger, S., \& Ron, S. (1983). Military Expenditure and Growth in Less Developed Countries. Journal of Conflict Resolution, 27(2), 335-353. https://doi.org/10.1177/0022002783027002006

Deger, S., \& Somnath, S. (1983). Military Expenditure, Spin-off and Economic Development. Journal of Development Economics, 13(1-2), 67-83. https://doi.org/10.1016/0304-3878(83)90050-0

Dongkyu, K. (2016). The Effects of Inter-State Conflicts on Foreign Investment Flows to the Developing World: Enduring Vs Ephemeral Risk of Conflicts. International Political Science Review, 37(4), 422-437. https://doi.org/10.1177/0192512115582278

Dunne, J. P., Eftychia, N., \& Ron, S. (2002). Military Spending, Investment and Economic Growth in Small Industrialising Economies. South African Journal of Economics, 70(5), 789-808. https://doi.org/10.1111/j.1813-6982.2002.tb00045.x

Dunne, J. P., Ron, P. S., \& Dirk, W. (2005). Models of Military Expenditure and Growth: A Critical Review. Defence and Peace Economics, 16(6), 449-461. https://doi.org/10.1080/10242690500167791

Enders, W., \& Todd, S. (1996). Terrorism and Foreign Direct Investment in Spain and Greece. Kyklos, 49(3), 331-352. https://doi.org/10.1111/j.1467-6435.1996.tb01400.x

Engle, R. F. (1974). Band Spectrum Regression. International Economic Review, 15(1), 1-11. https://doi.org/10.2307/2526084

Fatehi-Sedeh, K., \& Safzadeh, M. H. (1989). The Association between Political Instability and Flow of Foreign Direct Investment. Management International Review, 29(4), 4-13. https://doi.org/10.1016/0148-2963(94)90047-7

Feenstra, R. C., \& Taylor, A. M. (2014). International Economics, 19-20. New York: Worth Macmillan.

Frederiksen, P. C., \& Robert, E. L. (1982). Defense Expenditures and Economic Growth in Development Countries: Some Further Empirical Evidence. Journal of Economic Development, 7(1), 113-126.

Gastanaga, V. M., Jeffrey, B. N., \& Bistra, P. (1998). Host Country Reforms and FDI Inflows: How Much 
Difference Do They Make? World Development, 26(7), 1299-1314. https://doi.org/10.1016/S0305-750X(98)00049-7

Helpman, E., Marc, J. M., \& Stephan, R. Y. (2004). Export Versus FDI with Heterogeneous Firms. American Economic Review, 94(1), 300-16. https://doi.org/10.1257/000282804322970814

Hyung-Suk, B., Hyun-Hoon, L., \& Cyn-Young, P. (2012). Assessing Factors Affecting M\&As Versus Greenfield FDI in Emerging Countries. ADB Economics Working Paper Series no. 293. Manila, Philippines: Asian Development Bank. https://doi.org/10.2139/ssrn.2198156

International Monetary Fund (IMF). (1993). Balance of Payments Manual (5th ed.). Washington, D.C.: IMF.

Kennedy, G. (1974). The Military in Third Word. London: Duckworth.

Khalid, U. (2016). Catch-up in Institutional Quality: An Empirical Assessment. CREDIT Research Paper, (No. 2016-04). Nottingham: University of Nottingham. https://EconPapers.repec.org/RePEc:not:notcre:16/04

Khalid, U., \& Nusrate, A. (2019). Armed Conflict, Military Expenses and FDI Inflow to Developing Countries. https://doi.org/10.1080/10242694.2017.1388066

Kolstad, I., \& Line, T. (2002). Social Development and Foreign Direct Investments in Developing Countries. CMI Report R 2002:11. Bergen, Norway: Chr. Michelsen Institute. http://hdl.handle.net/11250/2435857

Landau, D. (1996). Is One of the 'Peace Dividends' Negative? Military Expenditure and Economic Growth in the Wealthy OECD Countries. The Quarterly Review of Economics and Finance, 36(2), 183-195. https://doi.org/10.1016/S1062-9769(96)90038-1

Landau, D. L. (1985). Government Expenditure and Economic Growth in the Developed Countries: 1952-76. Public Choice, 47(3), 459-477. https://doi.org/10.1007/BF00182148

Lee, H. (2017). Does Armed Conflict Reduce Foreign Direct Investment in the Petroleum Sector? Foreign Policy Analysis, 13(1), 188-214. https://doi.org/10.1111/fpa.12079

Leontief, W. W., \& Faye, D. (1983). Military Spending: Facts and Figures, Worldwide Implications, and Future Outlook. New York, NJ: Oxford University Press.

Li, Q. (2006). Political Violence and Foreign Direct Investment. Research in Global Strategic Management, 12, 231-255. https://doi.org/10.1016/S1064-4857(06)12011-2

Li, Q., \& Tatiana, V. (2010). Dyadic Military Conflict, Security Alliances, and Bilateral FDI Flows. Journal of International Business Studies, 41(5), 765-782. https://doi.org/10.1057/jibs.2009.91

Lim, D. (1983). Another Look at Growth and Defense in Less Developed Countries. Economic Development and Cultural Change, 31(2), 377-384. https://doi.org/10.1086/451326

Loree, D. W., \& Stephen, E. G. (1995). Policy and Non-Policy Determinants of US Equity Foreign Direct Investment. Journal of International Business $\quad$ Studies, 261-299. https://doi.org/10.1057/palgrave.jibs.8490174

Maizels, A., \& Machiko, K. N. (1987). The Causes of Military Expenditure in Developing Countries. In Saadet.

Majeed, \& Ahmad. (2006). Determinants of Exports in Developing Countries. The Pakistan Development Review, 45(4), 1265-1276. https://doi.org/10.30541/v45i4IIpp.1265-1276

Maslova, I., Onder, H., \& Sanghi, A. (2013). Growth and Volatility Analysis using Wavelets. World Bank Policy Research Working Paper (6578). The World Bank. https://doi.org/10.1596/1813-9450-6578

Mintz, A., \& Chi, H. (1990). Defense Expenditures, Economic Growth, and the 'Peace Dividend'. American Political Science Review, 84(4), 1283-1293. https://doi.org/10.2307/1963264

Nigh, D. (1985). The Effect of Political Events on United States Direct Foreign Investment: A Pooled Time-Series Cross Sectional Analysis. Journal of International Business Studies, 16(1), 1-17. https://doi.org/10.1057/palgrave.jibs.8490439

Noorbakhsh, F., Alberto, P., \& Ali, Y. (2001). Human Capital and FDI Inflows to Developing Countries: New $\begin{array}{llll}\text { Empirical } \quad \text { Evidence. } & \text { 1593-1610. }\end{array}$ https://doi.org/10.1016/S0305-750X(01)00054-7

Organisation for Economic Co-Operation and Development (OECD). (1996). Benchmark Definition of Foreign Direct Investment (3rd ed.). Paris: OECD.

Percival, D. B., \& Andrew, T. W. (2006). Wavelet Methods for Time Series Analysis (Vol. 4). Cambridge: 
Cambridge University Press.

Ram, R. (1995). Defense Expenditure and Economic Growth. In T. Sandler, \& K. Hartley (Eds.), Handbook of Defense Economics (pp. 251-274). Amsterdam: Elsevier. https://doi.org/10.1016/S1574-0013(05)80012-2

Resmini, L. (2000). The Determinants of Foreign Direct Investment in the CEECs: New Evidence from Sectoral Patterns. Economics of Transition, 8(3), 665-89. https://doi.org/10.1111/1468-0351.00060

Shang-Jin, W. (2000). Local Corruption and Global Capital Flows. Brooking Papers on Economic Activity, 31(2), 303-54. https://doi.org/10.1353/eca.2000.0021

Singhania, \& Saini. (2017). Determinants of FPI in Developed and Developing Countries. Global Business Review, 19(1), 187-213. https://doi.org/10.1177/0972150917713280

Stone, J. A., \& Hyun-Hoon, L. (1995). Determinants of Intra-Industry Trade: A Longitudinal, Cross-Country Analysis. Weltwirtschaftliches Archiv, 131(1), 67-85. https://doi.org/10.1007/BF02709072

Şule, L. A. (2008). Major Determinants of Imports in Turkey. Turkish Studies, 9(1), 131-145. https://doi.org/10.1080/14683840701814059

United Nations Conference on Trade and Development. (2007). World Investment Report 2007. New York, and Geneva: UNCTAD.

Walsh, J. P., \& Jiangyan, Y. (2010). Determinants of Foreign Direct Investment: A Sectoral and Institutional Approach. IMF Working Paper, WP/10/187. Washington, D.C.: IMF. https://doi.org/10.5089/9781455202218.001

Wheeler, D., \& Ashoka, M. (1992). International Investment Location Decisions: The Case of U.S. Firms. Journal of International Economics, 33(1-2), 57-76. https://doi.org/10.1016/0022-1996(92)90050-T

Zada, N., Muhammad, M., \& Bahadar, K. (2011). Determinants of Exports of Pakistan: A Country-wise Disaggregated Analysis. The Pakistan Development Review, 50(4), 715-732. https://doi.org/10.30541/v50i4IIpp.715-732

\section{Appendix}

\section{Countries List}

\begin{tabular}{|c|c|c|c|c|c|c|c|}
\hline Albania & Burkina Faso & Egypt & Hong Kong & Latvia & Namibia & Qatar & Syria \\
\hline Algeria & Cote d'Ivoire & El Salvador & Hungary & Lebanon & Netherlands & Romania & Tanzania \\
\hline Angola & Cameroon & Estonia & Iceland & Liberia & New Zealand & Russia & Thailand \\
\hline Argentina & Canada & Ethiopia & India & Libya & Nicaragua & Saudi Arabia & Togo \\
\hline Armenia & Chile & Finland & Indonesia & Lithuania & Niger & Senegal & Tunisia \\
\hline Australia & China & France & Iran & Luxembourg & Nigeria & Sierra Leone & Turkey \\
\hline Austria & Colombia & Gabon & Iraq & Madagascar & Norway & Singapore & Uganda \\
\hline Azerbaijan & Congo & Germany & Ireland & Malawi & Oman & Slovenia & Ukraine \\
\hline Bangladesh & Costa Rica & Ghana & Israel & Malaysia & Pakistan & South Africa & United Kingdom \\
\hline Bahrain & Croatia & Greece & Italy & Mali & Panama & South Korea & United States \\
\hline Belarus & Cuba & Guatemala & Jamaica & Malta & Papua New Guinea & Spain & Uruguay \\
\hline Belgium & Cyprus & Guinea & Japan & Mexico & Paraguay & Sri Lanka & Venezuela \\
\hline Bolivia & Czech Republic & Guinea-Bissau & Jordan & Moldova & Peru & Sudan & Vietnam \\
\hline Botswana & Denmark & Guyana & Kazakhstan & Mongolia & Philippines & Suriname & Yemen \\
\hline Brazil & Dominican Republic & Haiti & Kenya & Morocco & Poland & Sweden & Zambia \\
\hline Bulgaria & Ecuador & Honduras & Kuwait & Mozambique & Portugal & Switzerland & Zimbabwe \\
\hline
\end{tabular}

Source Author World bank with a total of 128 countries.

\section{Copyrights}

Copyright for this article is retained by the author(s), with first publication rights granted to the journal.

This is an open-access article distributed under the terms and conditions of the Creative Commons Attribution license (http://creativecommons.org/licenses/by/4.0/). 